\title{
Communications
}

\section{The Effect of Right-to-Work Laws on Unionization in the United States}

Keith Lumsden

Heriot-Watt University, Edinburgh

Craig Petersen

Utah State University

State right-to-work laws, the subject of considerable controversy in the industrial relations field, typically state that no person will be required to become a union member or, conversely, be required to abstain from union membership as a condition of obtaining or retaining employment.

Little hard evidence exists on the effect of right-to-work laws. Meyers (1955) concludes that in Texas the law does not appear to have had a noticeable impact on union strength. Kuhlman (1955) finds that the Virginia law has caused little change in hiring practices, and he cites lack of enforcement as a major cause. Novit (1969), in examining Indiana as the only state to pass a right-to-work law and subsequently repeal it, argues that the law was ineffective because unions found ways to circumvent its restrictions. During the period 1957-65 when the law was in force in Indiana, there was a dramatic increase in the agency shop which allows nonunion workers but which requires all employees to pay union dues. A Fortune (1957) survey of employers and union leaders in states with right-to-work laws concluded that the laws had little effect on overall union strength. In many states the laws were not being enforced, and in some instances employers were unwilling or unable to avoid de facto union shops. For example, in Arizona it was reported that the

We would like to thank (. C. Archibald, John Pencavel, James Rosse, M. W. Reder, and an anonymous referee for helpful suggestions and comments on a preliminary draft. [Journal of Political Economy, 1975, vol. 83, no. 6]

(C) 1975 by The University of Chicago. All rights reserved. 
attempt to hire a nonunion worker resulted in the union labor force calling in sick. Similarly, in Nevada, South Carolina, South Dakota, and Iowa, the survey found that unions were able to maintain union shop practices in spite of legislation to the contrary. One North Dakota legislator expressed his frustration by remarking, "It's a beneficial law to have, but there is no specific use for it right now" (Fortune 1957, p. 236).

In this paper we pursue the question of the effect of right-to-work laws beyond the impressionistic and fragmented evidence just cited and attempt to determine whether such laws significantly affect union membership. Since measuring the impact of right-to-work laws necessitates holding "other things" constant, a secondary product of this study is the assessment of the effect of other variables on union membership.

\section{A Model of the Supply and Demand for Union Services}

In this section we develop a simple theoretical model of the determinants of union membership by state. Following the approach of Pencavel (1971), we view the purchase of union membership as the result of utility-maximizing decision on the part of the individual worker. Specifically; membership is conceived as one of a number of forms in which the worker may choose to hold wealth. The decision to join a union as opposed to investing in another form of wealth can thus be analyzed using the standard theory of consumer choice. Consumer demand for an asset yielding services over a period of time is assumed a function of the individual's income $(Y)$, price $(P)$, the return of the asset relative to alternative assets $(R)$, and a vector of tastes and preferences of the worker $(T)$. In general,

$$
U_{D}=U_{D}(P, R, Y, T) .
$$

On the supply side, in the absence of a formal model, we assume that the level of union services provided is a function of the price of union membership and the costs of providing services. Costs include not only factor costs but also costs imposed by government policy, legislation concerning unions, and any real or psychological costs imposed by union leadership or rank-and-file members themselves, such as resistance to working with minority groups. Thus, the supply of union services can be written as

$$
L_{s}=L_{S}(P, C)
$$

where $C$ is a vector of variables which determine the cost of providing union services. If the equilibrium condition of the market for union services $\left(U_{S}=U_{D}=U\right)$ is imposed on the model, then equations (1) and (2) can be written

$$
\begin{aligned}
& U=U_{D}(P, R, Y, T), \\
& U=U_{S}(P, C) .
\end{aligned}
$$


Equations $\left(1^{\prime}\right)$ and $\left(2^{\prime}\right)$ form a system of two equations in two unknowns, $P$ and $U$. The system can be solved for the optimal values, $P^{*}$ and $U^{*}$. This is equivalent to deriving the reduced form of the model and results in two equations, each a function of all of the exogenous variables in the system. In that we are concerned only with the equilibrium level of union services, subsequent analysis is confined to the reduced-form equation

$$
U=U(Y, C, R, T) \text {. }
$$

\section{Data Requirements}

Transformation of the theoretical model of section I to an empirically estimable form necessitates an interpretation of the model in terms of the objectives of this paper, that is, measuring the effects of right-to-work laws and other variables on unionism in the United States. The observations in this study consist of data on the 48 states (Alaska and Hawaii are excluded because of data limitations) at a point in time. (In that the conventional interpretation of such cross sections is that of measuring an equilibrium relationship, we shall assume the equilibrium condition specified in eq. [3] holds in analyzing our data.)

The dependent variable is the percentage of the nonagricultural work force unionized. Because the model is derived in terms of the level of union services, a transition has to be made. This is accomplished by viewing one unit of union services as that quantity accruing to each union member and assuming that the quality of services does not vary systematically between states. The total union services consumed in a state are equivalent, therefore, to the number of union members in a state. The percentage unionized can then be interpreted as per capita consumption of union services.

Biannual union membership by state has been provided by the Bureau of Labor Statistics since 1964. The only source of similar data for any previous year is provided for 1939 and 1953 by Troy (1957). His data are not exactly comparable to the BLS data and probably underrepresent independent unions, especially in 1939. Because of the comparability problem, caution must be exercised in comparing the results of estimations using the Troy data with estimates based on the BLS information.

Along with 1939 and 1953 Troy data, 1968 BLS (1970) data were used. These data were the most recent available, and the choice of year provided relatively equal time intervals, 1939-53 and 1953-68. Table 1 summarizes union membership by state for the 3 years.

The income variable chosen is median wage and salary income in the state for the closest census year. Since most of the total income of union members is derived from wages and salaries, it will be assumed that the exclusion of other income will not introduce significant measurement bias.

Adequate data on the rate of return on alternative forms of wealth held 
TABLE 1

Union Membership as a Percentage of Nonagricultural Work Force by State, 1939, 1953, AND 1968

\begin{tabular}{|c|c|c|c|}
\hline State & 1939 & 1953 & 1968 \\
\hline Alabama ............... & 16.1 & 24.9 & 20.1 \\
\hline 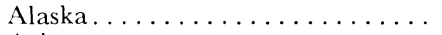 & NA $*$ & NA & 34.0 \\
\hline Arizona $\ldots \ldots \ldots \ldots \ldots$ & 16.6 & 27.7 & 18.9 \\
\hline 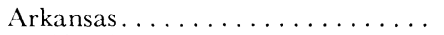 & 12.7 & 21.5 & 19.1 \\
\hline California .............. & 23.4 & 35.7 & 31.9 \\
\hline Colorado . . . . . . . . . . . & 17.6 & 27.8 & 21.8 \\
\hline Connecticut ............. & 11.3 & 26.5 & 23.7 \\
\hline 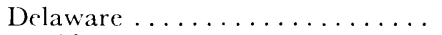 & 7.8 & 18.4 & 26.0 \\
\hline Florida . . . . . . . . . . . & 11.3 & 16.2 & 14.4 \\
\hline Georgia ............... & 7.0 & 15.0 & 16.6 \\
\hline Hawaii ................ & NA & NA & 27.5 \\
\hline Idaho $\ldots \ldots \ldots \ldots \ldots \ldots \ldots$ & 13.7 & 21.5 & 19.3 \\
\hline Illinois $\ldots \ldots \ldots \ldots \ldots \ldots$ & 25.9 & 39.7 & 36.0 \\
\hline Indiana $\ldots \ldots \ldots \ldots \ldots$ & 21.7 & 40.0 & 36.0 \\
\hline Iowa $\ldots \ldots \ldots \ldots \ldots \ldots \ldots$ & 17.3 & 25.0 & 21.3 \\
\hline Kansas . . . . . . . . . . . & 13.4 & 23.9 & 18.3 \\
\hline Kentucky . . . . . . . . . . . . . . & $22 . \overline{5}$ & 25.0 & 27.5 \\
\hline Louisiana . . . . . . . . . . . . & 9.6 & 19.5 & 18.0 \\
\hline 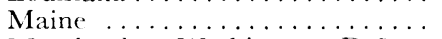 & 7.2 & 21.4 & 17.9 \\
\hline Maryland + Washington, D.C... & 12.0 & 25.2 & 22.6 \\
\hline Massachusetts ........... & 15.5 & 30.1 & 25.5 \\
\hline Michigan ............... & 20.0 & 43.3 & 36.2 \\
\hline Minnesota . . . . . . . . . . . & 24.8 & 38.1 & 30.2 \\
\hline Mississippi $\ldots \ldots \ldots \ldots \ldots \ldots$ & 6.5 & 14.7 & 13.8 \\
\hline Missouri . . . . . . . . . . . . & 21.9 & 39.7 & 36.0 \\
\hline Montana ............... & 36.7 & 47.0 & 31.3 \\
\hline Nebraska ................ & 12.5 & 19.7 & 17.2 \\
\hline Nevada $\ldots . . \ldots \ldots \ldots . . . . .$. & 18.2 & 30.4 & 29.4 \\
\hline New Hampshire . . . . . . . . . . & 7.3 & 24.6 & 17.5 \\
\hline New Jersey . . . . . . . . . . . . . . & 16.1 & 35.2 & 29.6 \\
\hline New Mexico .............. & 11.2 & 14.2 & 13.4 \\
\hline 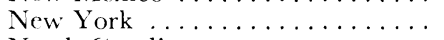 & 23.0 & 34.4 & 36.2 \\
\hline North Carolina . . . . . . . . . . & 4.2 & 8.3 & 7.5 \\
\hline North Dakota ............. & 10.9 & 15.6 & 18.8 \\
\hline 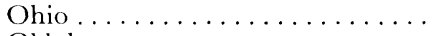 & 24.4 & 38.0 & 35.8 \\
\hline 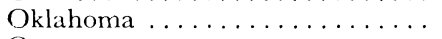 & 10.4 & 16.1 & 16.7 \\
\hline Oregon $\ldots \ldots \ldots \ldots \ldots$ & 30.1 & 43.1 & 31.6 \\
\hline Pennsylvania ............. & 27.6 & 39.9 & 37.3 \\
\hline Rhode Island $\ldots \ldots \ldots \ldots$ & 10.2 & 27.4 & 24.1 \\
\hline South Carolina . . . . . . . . . . & 4.0 & 9.3 & 8.6 \\
\hline South Dakota $\ldots . \ldots \ldots \ldots \ldots$ & 7.1 & 14.4 & 14.4 \\
\hline Tennessee ............... & 15.3 & 22.6 & 19.4 \\
\hline 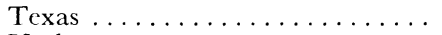 & 10.3 & 16.7 & 13.9 \\
\hline Utah $\ldots \ldots \ldots \ldots \ldots$ & 19.3 & 26.3 & 18.4 \\
\hline 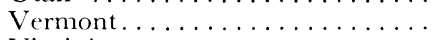 & 11.4 & 18.9 & 20.7 \\
\hline 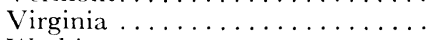 & 12.8 & 17.4 & 16.6 \\
\hline 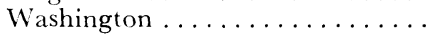 & 41.3 & 53.3 & 41.4 \\
\hline West Virginia .............. & 41.7 & 44.1 & 41.9 \\
\hline Wisconsin $\ldots \ldots \ldots \ldots \ldots$ & 29.1 & 38.3 & 32.2 \\
\hline Wyoming ............. & 26.7 & 28.6 & 18.5 \\
\hline U.S. total $\ldots \ldots \ldots \ldots \ldots$ & 21.5 & 32.6 & 28.4 \\
\hline
\end{tabular}

SOCrCes.-Troy (1957) for 1939 and 1953; U.S. Bureau of Labor Statistics (1970) for 1968

*Not available. 
by union members are not available. However, any potential sizable differences in the rate of return to assets between states should be eliminated by the flow of funds between states. Accordingly, the rate of return on alternative assets is assumed not to vary between states and is incorporated into a constant term of the estimating equation.

The cost of providing union services is probably subject to economies of scale. Once the basic structure of a union has been established in a given locale or industry, the marginal cost of serving an additional employee is small. We take the differences in cost between states to be most closely related to the scale of union operations in the state and the costs of adding new members and communicating with present members. The scale is proxied by the composition of industry in a given state. Mining, manufacturing, construction, and transportation-public utilities all have greater than 50 percent of their members unionized nationally, while wholesale and retail trade, services, government, and finance are substantially less organized. It is assumed that the average cost of providing union services is lower in those industries which have become highly unionized. Thus, the percentage of workers in mining, manufacturing, construction, and transportation-public utilities is included as proxies for cost. (As a practical matter, mining and manufacturing are combined because some states do not report them separately.)

If union leaders are prejudiced against the inclusion of certain groups in their movement and/or if workers are reluctant to associate with members of these or other groups, then the composition of the labor force may reflect a real or subjective difference in the cost of providing union services between the states. We take the percentage of nonwhites in a state's labor force and the percentage of females to be the most likely and widespread examples of discriminatory tastes.

The final determinant of cost is that imposed by government policy. If right-to-work laws are effective, then they make unionism more costly by eliminating the power of the union to coerce nonmember workers to join as a condition of employment. Memberships which would have been obtained by coercion now have to be made up by persuasion.

In the tastes and preferences vector of the demand function, we attempt to identify a number of the many dimensions of tastes and preferences by choice of variables for which data are available. It is alleged that females move in and out of the labor force more frequently than do males. Thus, the advantages of a union to females may be less significant. In addition, the domination of unions by males, by reducing the chance for female advancement within the union, may make membership less profitable. Racial minorities also are less likely to join unions because of a distaste for the almost exclusively white hierarchy of the union and exclusionary practices of white members.

The industrial composition of a state may also reflect the attitudes of the work force toward unionism. Presumably, workers who choose 
TABLE 2

States with Right-to-Work Laws As OF 1968

\begin{tabular}{|c|c|}
\hline State & Year of Adoption \\
\hline Alabama ........ & 1953 \\
\hline Arizona ......... & 1946 \\
\hline Arkansas........... & 1944 \\
\hline Florida $\ldots \ldots \ldots \ldots$ & 1944 \\
\hline Georgia $\ldots \ldots \ldots \ldots$ & 1947 \\
\hline Iowa............. & 1947 \\
\hline Kansas ............ & 1958 \\
\hline Mississippi . . . . . . & 1954 \\
\hline Nebraska . . . . . . . & 1946 \\
\hline Nevada ......... & 1951 \\
\hline North Carolina .... & 1947 \\
\hline North Dakota ..... & 1947 \\
\hline South Carolina .... & 1954 \\
\hline South Dakota ..... & 1946 \\
\hline Tennessee $\ldots \ldots \ldots$ & 1947 \\
\hline Texas ............ & 1947 \\
\hline Utah $\ldots \ldots \ldots \ldots$ & 1955 \\
\hline Virginia . . . . . . . & 1947 \\
\hline Wyoming ........ & 1963 \\
\hline
\end{tabular}

employment in an industry which is highly unionized have a more favorable attitude toward unions than do workers in other professions.

Another dimension of tastes and preferences is attitudes toward interference in the market mechanism. States with strong laissez-faire traditions are likely to view the power of the union and its infringement on the free market with suspicion. In that right-to-work laws are often enacted by vote of the populace, the existence of a right-to-work law may be indicative of antiunion sentiment. Table 2 lists states with such laws.

A better measure of tastes and preferences instead of the adoption or rejection of a state right-to-work law would include, first, the percentage of votes in a general state election for the adoption of such a law and, second, the degree to which the law, when in operation, was enforced in each state. Because such data are not readily available for a significant number of states, we include only adoption or nonadoption of a right-towork law as one of the independent variables. The inclusion of the variables discussed above yields (4), the final equation to be estimated:

$$
\begin{aligned}
& U=a_{0}+a_{1} P F E+a_{2} P N W+a_{3} P T R A N \\
& +a_{4} P M M+a_{5} P C O N+a_{6} I N C O M E+a_{7} R T W,
\end{aligned}
$$

where $P N I H$ and $P F E$ are the percentage of the work force that is nonwhite and female, respectively, $R T W$ is a dummy variable for states with right-to-work laws (or, in the case of the 1939 data, states that will 
eventually adopt right-to-work laws), INCOME is median wage and salary income, and $P M M, P C O N$, and $P T R A N$ are the percentage of the nonagricultural work force engaged in manufacturing and mining, construction, and transportation-public utilities, respectively.

The above analysis suggests that the coefficients of the income, mining and manufacturing, construction, and transportation-public utilities variables will be positive. The variables percentage nonwhite, percentage female, and existence of a right-to-work law are expected to be negatively associated with union membership.

Of particular interest is the right-to-work variable. The estimated coefficient, which represents the impact of right-to-work laws, may be measuring two effects. First, the passage or nonpassage of a law may reflect the tastes and preferences of the population. Second, the existence of a right-to-work law may raise the cost of unionization. Thus, the dual nature of the right-to-work variable complicates the interpretation of its coefficient. Any empirical investigation revealing that right-to-work laws are significantly negatively correlated with the extent of unionism may simply mean that, in states which have such laws, there is a strong bias against unions rather than any real antiunion effect of the law. A technique must be derived to separate the two effects. We attempt to do this in the following way. The Taft-Hartley Act was passed in 1947, and Troy's data provide us with union membership by state for a prior year, 1939, and for a later year, 1953. Although right-to-work laws were not in existence in 1939, we used, as a proxy measure of a state's tastes and preferences concerning unionization in that year, the information that 13 of the states would adopt right-to-work laws by 1953. We then estimated equation (4) for 1939 and 1953. For 1939, therefore, the right-to-work variable can reflect only tastes and preferences. For 1953, however, the variable will reflect not only tastes and preferences but also any effects which stemmed from the adoption of the right-to-work laws. If it is assumed that the role of the right-to-work variable as an indicator of tastes and preferences has not changed in the intervening period, then any additional impact found in 1953 must result from the effect of the laws. The statistical test is thus whether or not the estimated coefficient of the right-to-work variable for 1953 is significantly different from that estimated in 1939. If the hypothesis that they are equal can be rejected, then evidence has been found for the impact of right-to-work laws.

A similar test can be undertaken using 1968 data. By 1953, 13 states had right-to-work laws and six more adopted such laws between then and 1968, for a total of 19 states. If we examine the coefficient of the rightto-work variable in 1939 and in 1953, any difference reflects the impact of the passage of right-to-work laws if tastes and preferences are assumed constant. Examining the 1968 coefficient in comparison with the 1939 and 1953 coefficients provides evidence of the effect of such laws after the 
elapse of a substantial period of time. A finding of no right-to-work law effect in 1953 might be explained because the time lag was insufficient for their effect to become evident. A similar result for 1968, however, would provide a stronger case against the existence of any real effect.

Two additional tests of the effect of right-to-work laws are made using the data. First, equation (4) is estimated using first differences of the data, that is, the change in percentage unionized between periods is regressed as a function of changes in the independent variables over the same period. If right-to-work laws have obstructed union organization, then the coefficient of the right-to-work dummy should be negative.

Second, the period of time that a right-to-work law has been in force might be expected to be related to its impact on union membership. Taking the subset of states with right-to-work laws in 1968, the change in union membership over time in these states is regressed against the variables mentioned previously plus the number of years the state had such a law.

\section{Regression Results}

The results reported in this section are for estimation of equation (4) using as the right-to-work variable those states adopting a right-to-work law by 1968. They are summarized in table $3 .{ }^{1}$ The coefficient of the first variable, percentage of females in the labor force, is negative in each of the 3 years but statistically significant ${ }^{2}$ only in 1939. The coefficient of the variable, percentage of nonwhites in the labor force, is positive in 1939 and 1953 but not statistically significant in any year.

States with a higher proportion of workers engaged in transportation and public utilities are, ceteris paribus, more highly unionized, as expected. The coefficient of this variable is significant in 1939 and 1968. Positive and significant coefficients are also found for variable 4, percentage of the labor force in mining and manufacturing in 1939 and 1968. In 1953, the estimated coefficient is negative but not significant.

An unexpected finding is that the percentage of workers in construction is inversely related to unionization. The coefficient is negative for all 3 years and significant in 1968. A possible explanation is that, while the majority of construction workers are unionized, those states which have above-average employment in construction have a significantly larger

${ }^{1}$ Regressions, not reported here, were also made with the inclusion of variables reflecting variance in education, age, population growth, and urbanization between states. A number of different functional forms of the basic estimating equation were also tried. The conclusions regarding right-to-work laws and the other prime determinants of unionism were not substantively altered by these additions and variations.

${ }^{2}$ A 5 percent test will be the criterion for statistical significance throughout the analysis. 
TABLE 3

Factors Affecting Unionization by State

\begin{tabular}{|c|c|c|c|c|c|c|c|c|c|}
\hline \multirow[b]{2}{*}{ INDEPENDENT VARIABLES } & \multicolumn{3}{|c|}{1939} & \multicolumn{3}{|c|}{1953} & \multicolumn{3}{|c|}{1968} \\
\hline & Coefficient & $t$ Statistic & Mean & Coefficient & $t$ Statistic & Mean & Coefficient & $t$ Statistic & Mean \\
\hline Constant & 6.906 & 0.612 & 1.00 & 8.951 & 0.539 & 1.00 & -2.858 & -0.132 & 1.00 \\
\hline$\%$ female .. & $-0.885 *$ & -2.889 & 22.96 & -0.695 & -1.664 & 26.63 & -0.435 & -0.925 & 37.52 \\
\hline$\%$ nonwhite $\ldots \ldots \ldots \ldots \ldots$ & 0.161 & 1.407 & 10.81 & 0.268 & 1.840 & 9.82 & -0.071 & -0.073 & 10.78 \\
\hline$\%$ transportation-public utilities . . & $1.444 *$ & 2.679 & 10.50 & 0.318 & 0.486 & 9.37 & $2.517 *$ & 2.954 & 6.42 \\
\hline$\%$ mining and manufacturing $\ldots$. & $0.212 *$ & 1.690 & 32.78 & -0.020 & -0.119 & 32.50 & $0.320 *$ & 2.747 & 27.86 \\
\hline$\%$ construction $\ldots \ldots \ldots \ldots$ & -2.037 & -1.951 & 4.45 & -1.972 & -2.295 & 5.94 & $-2.194 * *$ & -2.257 & 5.26 \\
\hline Median wage and salary income. & $0.022^{*}$ & 2.912 & 793.17 & $0.021^{*}$ & 5.212 & 2110.65 & $0.006^{*}$ & 4.263 & 5745.44 \\
\hline $\begin{array}{l}\text { Right-to-work law } \\
R^{2}(\text { yes }=1 ; \text { no }=0) \ldots \ldots \ldots\end{array}$ & $-4.636 *$ & $\begin{array}{c}-1.946 \\
.62\end{array}$ & 0.40 & $-4.474^{*}$ & $\begin{array}{c}-1.687 \\
.67\end{array}$ & 0.40 & $-3.391 *$ & $\begin{array}{c}-1.697 \\
.72\end{array}$ & 0.40 \\
\hline$R^{2} \ldots \ldots \ldots \ldots \ldots \ldots$ & $\ldots$ & .62 & $\cdots$ & $\ldots$ & .67 & $\cdots$ & $\ldots$ & .72 & $\cdots$ \\
\hline
\end{tabular}

*One-tailed test significant at $5{ }^{\prime \prime}$.

**Two-tailed test significant at $5 \%$ (sign opposite that predicted by the model). 
number of nonunion construction employees. Unfortunately, the data required to test that hypothesis are not available.

As was hypothesized, the coefficient on variable 6 , median wage and salary income, is positive. In each year the coefficient is highly significant. We have implicitly assumed the income variable to be exogenously determined. If, however, unions succeed in raising wages, income will be endogenous and will be simultaneously determined with degree of unionization. As a result, the regression coefficient may be biased. The position that income is exogenous may be justifiable, however, on two bases. First, previous work, both theoretical and empirical, has not suggested a high degree of unionization-high wage causal relationship that is significant for many industries over time (see Reder 1958 and Lewis 1963). Second, even if unions raise wages in the union sector, it is quite possible that wages will be depressed below their market levels in nonunion sectors so that the net effect of unionization on the median wage is indeterminate.

The coefficient of the right-to-work variable is negative and statistically significant in all 3 years. The 1939 value of the estimated coefficient $(-4.636)$ is interpreted as follows. For 1939, in states which would have a right-to-work law by 1968, union membership was, on average, 4.64 percent lower than in states which did not adopt right-to-work laws, ceteris paribus. Since right-to-work laws did not exist in any state in 1939, this significant difference in union members is interpreted as being due to differences in tastes and preferences for unionization.

In 1953, in the 19 states that either had right-to-work laws by this time or would have them by 1968, the right-to-work variable exerts a depressant effect on union membership of 4.47 percent. Since, in 1953, 13 states had right-to-work laws, the coefficient for 1953 includes both the tastes and preferences effect of the right-to-work variable, and also any impact the actual passage of the law in the 13 states had had up to that time. If tastes and preferences are assumed constant from 1939 to 1953, then any impact of the passage of right-to-work laws as of 1953 should be manifested by a larger coefficient in 1953 than in 1939. A relevant statistical test is Hotelling's $T^{2}$ test of the difference between two estimated coefficients. Since the 1953 coefficient is smaller than the 1939 coefficient, it is not necessary to perform the formal test. The influence of the rightto-work variable is smaller in 1953 compared with 1939, not greater as would be expected if the laws have a negative effect on union membership. Thus, the hypothesis of no impact of right-to-work laws cannot be rejected as of 1953 .

For 1968, the right-to-work variable has a coefficient of -3.39 . This is smaller in absolute value than either 1939 or 1953. Subject to the caution of comparing the 1968 data with those of the 2 earlier years, we again conclude that the hypothesis of no impact of the law cannot be 
TABLE 4

Factors Affecting Changes in Unionization, 1939-68

\begin{tabular}{|c|c|c|c|}
\hline Independent Variable & Coefficient & $t$ Statistic & Mean \\
\hline & \multicolumn{3}{|c|}{ A. All States } \\
\hline Constant......... & -32.835 & -0.325 & 1.00 \\
\hline Female .......... & -0.096 & -0.367 & 145.58 \\
\hline Nonwhite $\ldots \ldots \ldots \ldots \ldots \ldots \ldots$ & -0.035 & -0.353 & -0.250 \\
\hline Transportation-public utilities ..... & $1,407.051^{*}$ & 3.499 & -0.04 \\
\hline Mining and manufacturing $\ldots \ldots \ldots$ & 80.098 & 0.623 & -0.049 \\
\hline Construction $\ldots \ldots \ldots \ldots \ldots \ldots$ & -740.775 & -0.949 & 0.001 \\
\hline Income $\ldots \ldots \ldots \ldots \ldots \ldots \ldots$ & $0.037 *$ & 2.199 & $4,952.02$ \\
\hline Right-to-work law $\ldots \ldots \ldots \ldots \ldots$ & -1.754 & -0.098 & 0.40 \\
\hline \multirow[t]{2}{*}{$R^{2} \ldots \ldots \ldots \ldots \ldots \ldots \ldots \ldots \ldots \ldots \ldots$} & $\ldots$ & .45 & $\cdots$ \\
\hline & \multicolumn{3}{|c|}{ B. States Adopting Right-to-Work Laws by } \\
\hline Constant ......... & -257.783 & -1.443 & 1.00 \\
\hline Female .......... & 0.769 & 1.842 & 159.95 \\
\hline Nonwhite . . . . . . . . . . . . . . & -0.183 & -1.167 & -45.74 \\
\hline Transportation-public utilities ..... & $1,283.048^{*}$ & 2.045 & -0.05 \\
\hline Mining and manufacturing $\ldots \ldots \ldots$ & 85.676 & 0.495 & -0.03 \\
\hline Construction $\ldots \ldots \ldots \ldots \ldots \ldots$ & $-1,434.048$ & -1.411 & 0.01 \\
\hline Income $\ldots \ldots \ldots \ldots \ldots \ldots \ldots$ & 0.046 & 1.338 & $4,576.31$ \\
\hline Years in effect ................ & 1.865 & 1.023 & 17.84 \\
\hline$R^{2} \ldots \ldots \ldots \ldots \ldots \ldots \ldots \ldots \ldots \ldots$ & $\ldots$ & .53 & $\ldots$ \\
\hline
\end{tabular}

*One-tailed test significant at $5 \omega_{0}$.

rejected. Our general conclusion, therefore, with regard to states which have adopted right-to-work laws is that they hold significantly different attitudes regarding unionization than do the remainder of the states but that no evidence exists of any significant impact on unionization of the actual right-to-work laws themselves.

The second test of the effect of right-to-work laws involves the use of first differences of the data. The change in unionization between 1939 and 1968 was regressed as a function of changes in the other variables over the same period. The results are summarized in table 4, part A. The right-to-work variable is not statistically significantly different from zero. ${ }^{3}$ The only variables that are statistically significant are the change in income and the change in employment in transportation and public utilities. Both coefficients are positive, as suggested in section II.

The third test of the effect of right-to-work laws incorporates a variable representing the number of years a state had a right-to-work law in force by 1968 . These results are reported in table 4, part B. Using the subset of states which had passed such laws by 1968, the first difference data were again used. The length of time since passage of a law was not found

${ }^{3}$ Although not explicitly reported here, similar findings held for the subperiods 1968 minus 1953 and 1953 minus 1939. 
to be significantly related to the change in union membership. The only statistically significant coefficient is that of variable 3, proportion of workers engaged in transportation and public utilities.

\section{Summary and Conclusions}

In this paper we have attempted to determine the effect of right-to-work laws on union membership. It was found that states with such laws have a significantly smaller percentage of their work force unionized but that the difference reflects tastes and preferences of the population rather than a substantive impact of the laws themselves. Analysis of changes in union membership in states with and without right-to-work laws and using the number of years a law has been in force yielded similar conclusions. Thus, we align ourselves with prevailing suspicions that the battle for right-towork laws is one of symbol rather than substance.

\section{References}

Fortune 56 (September 1957): 235-41.

Kuhlman, John M. "Right-to-Work Laws: The Virginia Experience." Labor Law J. 6 (July 1955): 453-61.

Lewis, H. Gregg. Unionism and Relative Wages in the United States. Chicago: Univ. Chicago Press, 1963.

Meyers, Frederick. "Effects of 'Right-to-Work' Laws: A Study of the Texas Act." Industrial and Labor Relations Rev. 9 (October 1955): 77-84.

Novit, Mitchell S. "Right-to-Work: Before and After." Bus. Horizons 12 (October 1969): 15-18.

Pencavel, John H. "The Demand for Union Services: An Exercise." Industrial and Labor Relations Rev. 24 (January 1971): 180-90.

Reder, Melvin W. "Wage Determination in Theory and Practice." In A Decade of Industrial Relations Research. New York: Harper, 1958.

Troy, Leo. Distribution of Union Membership among States, 1939 and 1953. Occasional Paper no. 56. New York: Nat. Bur. Econ. Res., 1957.

U.S. Bureau of Labor Standards. State Right-to-Work Laws. Bulletin 204. Washington: Government Printing Office, 1960.

U.S. Bureau of Labor Statistics. Directory of National and International Labor Unions in the United States, 1969. Bulletin no. 1665. Washington: Government Printing Office, 1970. 